\title{
Book News
}

The American Mail, Enlarger of the Common Life, by Wayne E. Fuller. Chicago: University of Chicago Press, 1972, pp. xi, 378.

WAYNE E. FULLER WROTE ABOUT the establishment of rural free delivery of mail in Hardin County, lowa in the Fall 1972 issue of the Annals. His book records and interprets the history of American postal service. It provides yet another means for viewing American history: showing the progress of technology (the impact of the railroad, the automobile, and the airplane) and presenting the debates over innovation (over the postage stamp, free home delivery, RFD, parcel post, and airmail).

Mr. Fuller describes the organization of the postal service and the various techniques that have been devised for handling the mail. He points up the uniqueness and democratic nature of the American mail. The rural press, for example, was carefully nurtured by the postal service. By an act of Congress, newspapers were permitted to be sent through the mails at "incredibly low postage rates." Mr. Fuller notes that "Most of the great debates on the Post Office in Congress from the 1790 s to World War I touched in one way or another on the need to retain the franking privilege and reduce the postage on printed matter in order to develop an enlightened public opinion." The American Mail is one of the books in the "Chicago History of American Civilization" series, edited by Daniel J. Boorstin. In his preface, Mr. Boorstin states that this book fulfills the purpose of the series "which aims to make each aspect of our culture a window to all our history."

Correction: Vol. 41 , No. 8 , page 1281 , 2nd paragraph, 4 th sentence should read, "Whereas Buck too readily assumed a causal relationship between agrarian-antimonopoly conventions and subsequent regulatory legislation, Miller tends towards the opposite extreme. 
Copyright of Annals of Iowa is the property of State of Iowa, by \& through the State Historical Society of Iowa and its content may not be copied or emailed to multiple sites or posted to a listserv without the copyright holder's express written permission. However, users may print, download, or email articles for individual use. 